\title{
Hot oceanography: planktivorous seabirds reveal ecosystem responses to warming of the Bering Sea
}

\author{
Alan M. Springer ${ }^{1, *}$, G. Vernon Byrd ${ }^{2}$, Sara J. Iverson ${ }^{1,3}$ \\ ${ }^{1}$ Institute of Marine Science, University of Alaska Fairbanks, Fairbanks, Alaska 99775-7220, USA \\ ${ }^{2}$ Alaska Maritime National Wildlife Refuge, US Fish and Wildlife Service, 95 Sterling Highway, Suite 1, Homer, \\ Alaska 99603, USA \\ ${ }^{3}$ Department of Biology, Dalhousie University, Halifax, Nova Scotia B3H 4J1, Canada
}

\begin{abstract}
The Bering Sea has experienced dramatic warming in this century that has altered elements of the ecosystem, including the structure and productivity of the zooplankton community on the continental shelf, and the extent to which waters and associated plankton of oceanic origin have intruded onto the shelf. We documented temporal and spatial scales of these changes by monitoring diets of least auklets Aethia pusilla on the Pribilof Islands - least auklets are planktivores that specialize on the large calanoid copepods Neocalanus spp. from the basin and Calanus marshallae from the shelf. Diets were estimated in the summers of 1996 to 2006 by enumerating prey in regurgitated meals brought to chicks by adults, and by fatty acid analyses of live biopsy samples of adipose tissue from adult birds in 2003 and 2004, which provided additional insight. In the unusually warm 2000s, Neocalanus spp. apparently were excluded from regions of the outer shelf, where they typically occur in cooler years, and, concurrently, C. marshallae was depressed over a large region of the shelf because of chronic failures of spring cohorts to survive. Both changes were associated with anomalously high water temperatures over the middle shelf. The information provided by least auklets greatly improves our understanding of the consequences of environmental change and supplies clues about how communities and ecosystem processes respond to physical forcing. Continued warming of the magnitude seen in recent years could become a cause for concern for auklets and other planktivores in the eastern Bering Sea if it alters prey availability in ways detrimental to their populations.
\end{abstract}

KEY WORDS: Bering Sea $\cdot$ Climate change $\cdot$ Seabird $\cdot$ Auklet $\cdot$ Diet $\cdot$ Copepod $\cdot$ Oceanography

\section{INTRODUCTION}

Warming of the climate system is unequivocal, as is now evident from observations of increases in global average air and ocean temperatures, widespread melting of snow and ice, and rising global average sea level....Anthropogenic warming and sea level rise would continue for centuries due to the timescales associated with climate processes and feedbacks, even if greenhouse gas concentrations were to be stabilized.

IPCC (2007)

Climate change in the past 3 decades in the North Pacific is thought to have had major effects on marine ecosystems, from physical oceanography to population dynamics of a variety of species (e.g. Ebbesmeyer et al. 1991, Francis \& Hare 1994, Anderson \& Piatt 1999, Hare \& Mantua 2000). The eastern Bering Sea in particular has undergone dramatic warming in this century, as predicted by global climate models, that has apparently had significant effects on pelagic and benthic community structure and biomass yield (Grebmeier et al. 2006, Coyle et al. 2008, IPCC 2007, Stabeno et al. 2007). Yet, despite intense interest, the mechanisms linking meteorological and oceanographic variability to marine biology and productivity are poorly known, owing largely to the high costs of extensive ship-based oceanographic studies designed specifically to document change and to discover its cause.

Insights into relationships among marine communities, food webs, and oceanographic features can often be found by examining characteristics of species at 
higher trophic levels because they integrate processes at multiple lower trophic levels. Diet studies of predators can be especially informative because forage species and food webs are commonly affected by physical processes and variability. In the Bering Sea, least auklets Aethia pusilla have been shown to be especially useful in elucidating ecosystem properties that have much broader implications than simply for the birds and their prey (e.g. Springer \& Roseneau 1985).

Least auklets are one of the most numerous and widely distributed species of seabirds in the Bering Sea - they number in the millions and nest at island colonies from the Aleutian Islands to Bering Strait (Jones 1993). They are planktivores that specialize on the large calanoid copepods Neocalanus cristatus, $N$. plumchrus, N. flemingeri, and Calanus marshallae in summer, and supplement them with other taxa of zooplankton, such as hyperiid amphipods, euphausiids, crab, shrimp, and fish larvae, and other miscellaneous organisms (Bedard 1969, Hunt et al. 1981, Bradstreet 1985, Springer \& Roseneau 1985, Roby \& Brink 1986, Hunt \& Harrison 1990, Flint \& Golovkin 2002). The composition of the copepod portion of their diets is determined by the relative abundances of the various species, which are in turn influenced by physical processes that structure the Bering Sea into hydrographic and biotic domains with distinct species assemblages (Iverson et al. 1979, Cooney 1981, Coachman 1986, Springer et al. 1996). Interannual variation in physical conditions and primary production can also affect copepod population abundances (Smith \& Vidal 1984, 1986). Furthermore, in regions where all 4 species of copepods are available within the foraging range of least auklets, selectivity for one or another species appears to be determined not by differences in nutritional/energetic content, which are small, but by the ability of birds nesting in distinct colonies to find profitable solutions for dietary proclivities (Springer \& Roseneau 1985, Flint \& Golovkin 2002).

Oceanographic conditions in the southeastern Bering Sea in late July to August 2004, documented by traditional shipboard methodologies, sharply partitioned continental shelf and oceanic domains and created an abrupt and extremely narrow ecotone between them (Coyle et al. 2008). That is, waters of oceanic origin were confined to the very outer part of the continental shelf, with little or no excursion onto the shelf or mixing with waters of the middle shelf domain. Least auklet diets from the Pribilof Islands during summer 2004, which we present here, were indicative of this unusual hydrographic structure. Therefore, we examined our auklet diet data from the Pribilof Is. for 1996 to 2006, and reviewed data from earlier years (St. George I.1977, 1984, 1985; St. Paul I.-1976, 1977, 1984, 1992), to see if there was evidence that such conditions had occurred at other times in the past 3 decades. This is among the few data sets that can be used to document the temporal and spatial scale of conditions important to the structure of the pelagic community of continental shelf waters, to the food web supporting least auklets and other planktivorous species at the Pribilof Is., and thus to our view of how climate change may alter characteristics of the marine ecosystem of the Bering Sea. The Pribilof Is. are well situated for such studies: central-place foragers like least auklets on St. George I. are closer to deep basin waters and the associated oceanic plankton community than auklets on St. Paul I., which is somewhat higher on the continental shelf, and thus, birds from the 2 islands sample the region differently and provide contrasting and complementary views of the larger ecosystem.

\section{MATERIALS AND METHODS}

Samples for estimating least auklet diets were obtained during the nesting season (June through early August) from 1996 to 2006, from adults trapped at colonies on St. George I. and St. Paul I. (Fig. 1, Table 1), largely as part of a long-term seabird monitoring program conducted by the Alaska Maritime National Wildlife Refuge (e.g. Dragoo et al. 2006). Contents of sublingual pouches, consisting of fresh zooplankton destined for chicks, were collected when the birds regurgitated upon being trapped. In 2003 and 2004 on St. Paul I., adipose tissue samples for fatty acid signature analysis were also taken by live biopsy from the

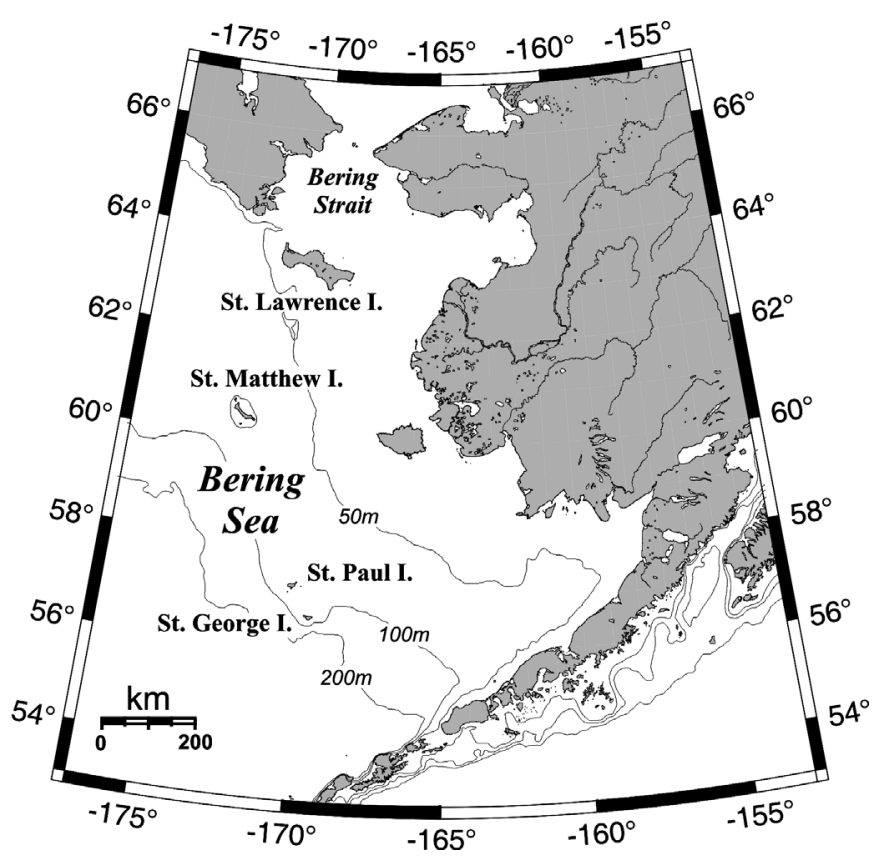

Fig. 1. Pribilof Islands and other locations discussed in the text 
Table 1. Aethia pusilla. Sample sizes and dates when diet samples were collected at the Pribilof Islands. Asterisks denote samples for fatty acids; all others are regurgitations

\begin{tabular}{|c|c|c|c|c|c|c|c|c|c|c|}
\hline & $\begin{array}{r}\text { June } \\
\text { Date/Interval }\end{array}$ & $\mathrm{n}$ & $\begin{array}{l}\text { Early July } \\
\text { Date/Interval }\end{array}$ & $\mathrm{n}$ & $\begin{array}{l}\text { Mid-July } \\
\text { Date/Interval }\end{array}$ & $\mathrm{n}$ & $\begin{array}{r}\text { Late July } \\
\text { Date/Interval }\end{array}$ & $\mathrm{n}$ & $\begin{array}{r}\text { Early Augus } \\
\text { Date/Interval }\end{array}$ & $\mathrm{n}$ \\
\hline \multicolumn{11}{|c|}{ St. George I. } \\
\hline 1996 & & & & & Jul 21 & 20 & & & & \\
\hline 1997 & & & & & Jul 21 & 21 & Jul 31 & 14 & & \\
\hline 1998 & & & & & Jul 19 & 4 & Jul 30 & 12 & & \\
\hline 1999 & & & & & & & & & Aug 2 & 14 \\
\hline 2000 & & & & & & & Jul 25 & 15 & Aug 6-7 & 20 \\
\hline 2001 & & & & & & & Jul 24-30 & 15 & & \\
\hline 2002 & & & & & Jul 17 & 13 & Jul 27-28 & 18 & & \\
\hline 2003 & & & Jun 29-Jul 3 & 14 & Jul 11 & 11 & Jul 29-Aug 1 & 22 & & \\
\hline 2004 & & & Jun 30-Jul 6 & 11 & & & Jul 25-27 & 8 & & \\
\hline 2005 & & & Jul 1-4 & 20 & Jul 12-23 & 15 & Jul 23-Aug 1 & 17 & & \\
\hline 2006 & & & & & Jul 6-22 & 19 & & & & \\
\hline \multicolumn{11}{|c|}{ St. Paul I. } \\
\hline 1996 & & & & & Jul 14 & 15 & & & & \\
\hline 1997 & & & & & Jul 18-21 & 10 & Jul 22-31 & 7 & & \\
\hline 1998 & & & & & Jul 18-24 & 7 & Jul $27-29$ & 8 & & \\
\hline \multicolumn{11}{|l|}{1999} \\
\hline 2000 & & & & & Jul 17-22 & 43 & Jul 24-30 & 52 & Aug 1-10 & 26 \\
\hline 2001 & & & & & & & Jul 24-31 & 12 & Aug 1-9 & 15 \\
\hline 2002 & & & & & & & & & Aug 2 & 7 \\
\hline 2003 & & & Jul 7 & 12 & Jul 12-19 & 13 & Jul 24-31 & 12 & & \\
\hline $2003^{*}$ & Jun 2-12 & 10 & & & Jul 12-15 & 16 & & & & \\
\hline 2004 & & & Jun 30-Jul 13 & 67 & Jul 19-23 & 38 & Jul 25-31 & 10 & & \\
\hline $2004^{*}$ & Jun 1-11 & 25 & & & & & Jul 25-29 & 17 & & \\
\hline 2005 & & & Jul 5-7 & 3 & Jul 21 & 2 & & & & \\
\hline 2006 & & & & & Jul $12-17$ & 13 & & & & \\
\hline
\end{tabular}

synsacral region of the birds (Iverson et al. 2007, this volume). All birds were released after sampling. Regurgitation samples were preserved in $70 \%$ ethanol in the field and enumerated at the University of Alaska Fairbanks using methods described by Springer \& Roseneau (1985). Prey species were identified to the lowest taxonomic level practical, which precluded separating the closely related copepod species Neocalanus plumchrus and $N$. flemingeri. Adipose tissues were placed in chloroform buffered with BHT (an antioxidant) and frozen until analyzed using methods described by Iverson et al. (2007).

\section{RESULTS}

\section{Diets at St. George I. - adult regurgitations of chick meals}

Diets of least auklets during our study at St. George I. were in most respects typical of those reported in earlier years - that is, large calanoid copepods dominated diets in nearly all intervals in all years, with other taxa present in varying, lesser proportions (Fig. 2a, Table 2). Among the copepods, Neocalanus cristatus and $N$. plumchrus/flemingeri were generally, but not

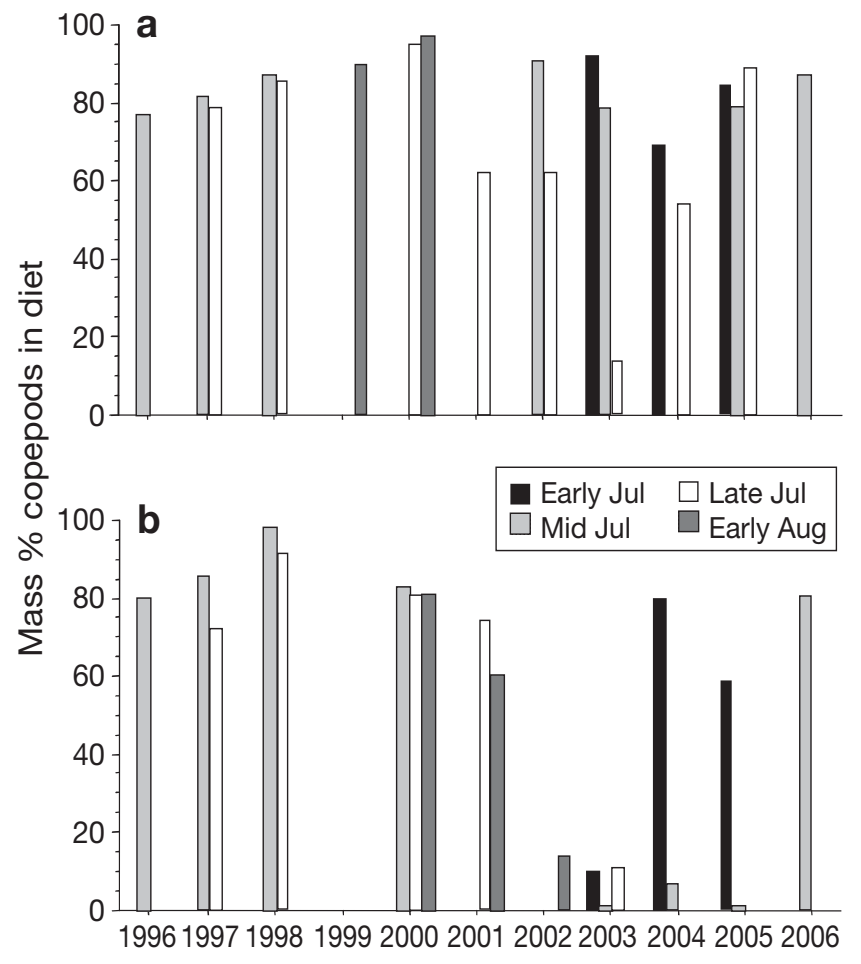

Fig. 2. Aethia pusilla. Least auklet diets at the Pribilof Islands - (a) St. George I. and (b) St. Paul I., from 1996 to 2006 


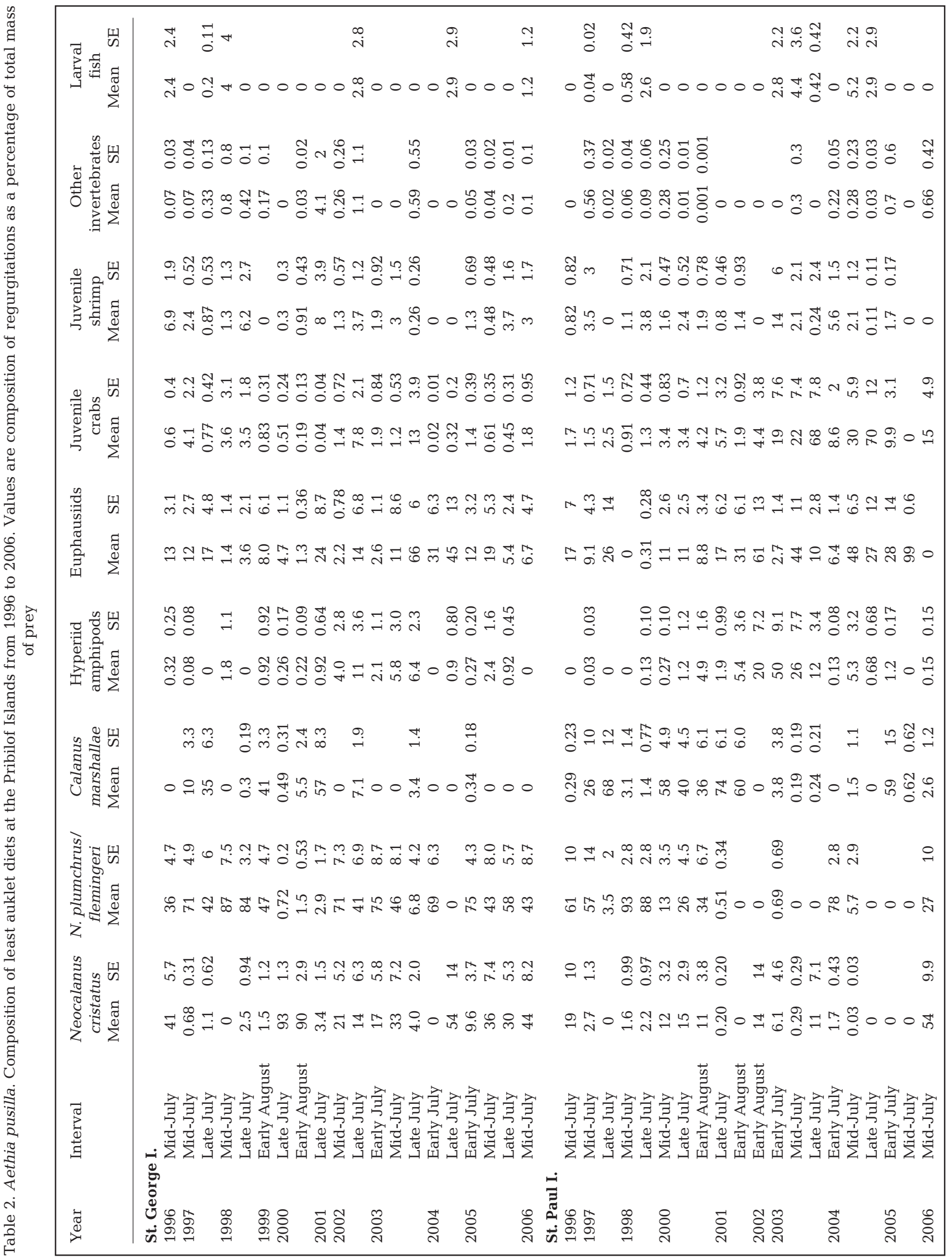


always, more important than Calanus marshallae. Only in late July 2003 did copepods contribute relatively little to auklet diets.

\section{Diets at St. Paul I. — adult regurgitations of chick meals}

In contrast to St. George I., copepods were frequently ( 7 of 9 intervals) rare or absent from auklet diets at St. Paul I. from 2002 to 2005 (Fig. 2b, Table 2). This was remarkably dissimilar to diets there from 1996 to 2001 and to those previously reported from the Pribilof Is. or elsewhere. Copepods were hardly encountered in any of the 3 intervals sampled in 2003; and in 2004 and 2005 they were plentiful in early July, but declined abruptly and precipitously later in those summers. Furthermore, copepods were not abundant in late July 2002, the only interval sampled that summer. By 2006, copepods were again abundant in midJuly, a time by which, in the previous $2 \mathrm{yr}$ at least, they had already essentially disappeared. At times when copepods were not plentiful, least auklets ate primarily hyperiid amphipods, euphausiids, and juvenile crabs (Table 2).

Calanus marshallae was absent in diets, or nearly so, in all intervals we sampled from 2002 to 2004, and in mid-July 2006, when Neocalanus spp. were present (Table 2). C. marshallae was plentiful in early July 2005, when Neocalanus were absent, but disappeared from diets by the middle of the month.

\section{Diets at St. Paul I. — adult fatty acids}

Calanoid copepod fatty acids are distinguished from fatty acids of all other marine species by the extremely large proportions of long-chain monounsaturated fatty acids and fatty alcohols (especially the isomers 20:1n-11, 20:1n-9, 22:1n-11, and 22:1n-9) arising from de novo biosynthesis (reviewed in Dalsgarrd et al. 2003); this is consistent with our own data on the fatty acid composition of both Neocalanus spp. and Calanus marshallae (S. J. Iverson unpubl. data). These fatty acid biomarkers of copepods in least auklet adipose tissue were found at very high levels on St. Paul I. in early June in both 2003 and 2004 (Fig. 3), indicating that copepods had been available to them approximately 2 to $4 \mathrm{wk}$ (the approximate integration period of dietary fatty acids) before the first chick meals were collected in early July. By July 2004, these fatty acid isomers had declined, but not to as low levels as by July 2003, which is consistent with the later decline of copepods in 2004 that was evident from chick meals.

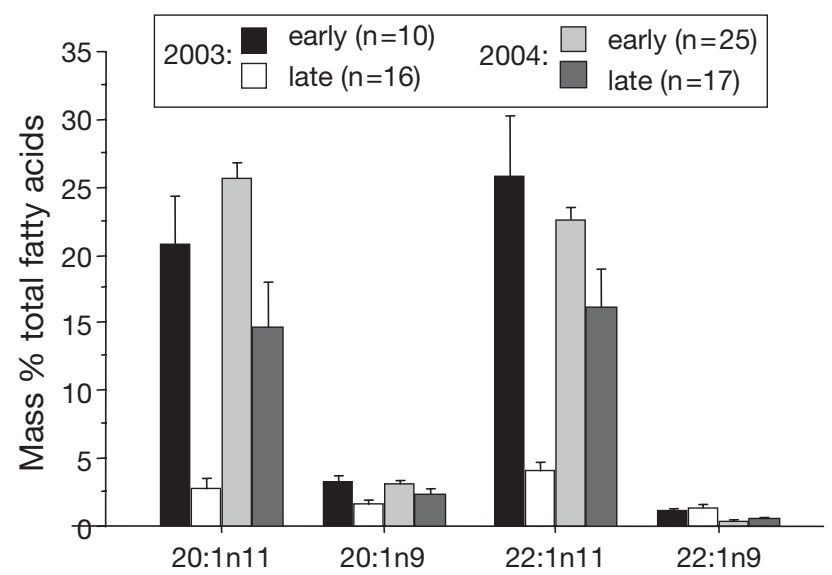

Fig. 3. Aethia pusilla. Characteristic copepod fatty acid biomarkers (mean $\pm \mathrm{SE}$ ) measured in adipose tissue biopsies obtained from adult least auklets in June (early) and July (late) of 2003 and 2004 on St. Paul I.

\section{DISCUSSION}

\section{Interannual and inter-island variability}

The diets of least auklets Aethia pusilla at St. George I. that we observed from 1996 to 2006 were similar to those reported for the chick periods in 1977, 1984, and 1985 (Hunt et al. 1978, Bradstreet 1985, Roby \& Brink 1986). Copepods predominated in all sampling periods except late July 2003. Among all copepods, Neocalanus spp. predominated in all but 1 collection, when they were replaced by Calanus marshallae.

St. George I. lies near the oceanic domain, the habitat of Neocalanus spp., which are endemic to oceanic waters of the North Pacific and Bering Sea and are supplied to the outer continental shelf by advection. Calanus marshallae replaces Neocalanus on the shelf, where it is the only large calanoid species (Cooney 1981). Neocalanus are larger than C. marshallae and might have been selected preferentially over C. marshallae by auklets if both were equally available (i.e. Neocalanus might be more profitable in an energetic sense). Lack of C. marshallae in diets, therefore, would not necessarily indicate a lack of $C$. marshallae in the environment. Thus, Neocalanus spp. were apparently much less abundant/profitable than $C$. marshallae in late July 2001, the only interval (of 20 intervals in $11 \mathrm{yr}$ in our study) when C. marshallae was dominant at St. George I., although it was of about equal importance as Neocalanus at times in 1997 and 1999. C. marshallae was apparently much more profitable than Neocalanus within the foraging range of auklets at St. Paul I. at times in 1997, 2000, 2001 and 2005. In the same vein, the switch from $N$. plumchrus/flemingeri in early July to N. cristatus in late July 2004 at St. George I. 
likely reflected a change in the profitability of these species: all samples were collected from the Ulakaia Hill colony, minimizing the possibility that dietary specialization by birds at individual colonies might have accounted for the difference (Springer \& Roseneau 1985, Flint \& Golovkin 2002).

A much different picture emerged at St. Paul I., where copepods predominated in diets from 1996 to 2001, but thereafter occurred only during early summer. They were nearly gone, at the latest, by early August 2002, by early July 2003, and by mid-July 2004 and 2005. In 2006, Neocalanus and Calanus marshallae were again abundant in diets in mid-July, a time by which they had essentially disappeared in the previous 2 yr. Diets from 2002 to 2005 contrasted not only with those from 1996 to 2001 and 2006, but also with those in 1976, 1977, 1984, and 1992, when copepods dominated throughout the chick period (Hunt et al. 1978, Bradstreet 1985, Flint \& Golovkin 2002).

As noted earlier, St. Paul I. lies higher on the continental shelf than St. George I. and is therefore not as near to the deep basin, and the source of Neocalanus spp. Moreover, the location of St. Paul I. places it somewhat more within the realm of Calanus marshallae, a shelf species, than St. George I. Although auklets at St. Paul I. commonly have access to copepods in summer, obviously there can be situations when foraging areas influenced by oceanic waters, i.e. where Neocalanus would be expected, are apparently beyond the profitability range of these small seabirds. St. Paul I. lies just $75 \mathrm{~km}$ north of St. George I., and although the foraging range of least auklets can be as great as 80 to $100 \mathrm{~km}$, depending on prey distributions (Obst et al. 1995, Flint \& Golovkin 2002), from 2002 to 2005 Neocalanus were out of range of birds from St. Paul I. much of the time. And, not only were Neocalanus commonly unavailable to auklets at St. Paul I. from 2002 to 2005, there were few C. marshallae either.

\section{Causes of copepod anomalies}

The unusual paucity of Calanus marshallae in continental shelf waters and the sharp demarcation between shelf and oceanic zooplankton communities from 2002 to 2005 were documented by traditional sampling with plankton nets in a single cruise in late July through September 2004 (Coyle et al. 2008). Depleted Neocalanus abundances around St. Paul I. at that time were apparently caused by a very sharp boundary between oceanic and shelf water masses (the Middle Front) that restricted the oceanic zooplankton community to the deeper offshore region beyond the reach of foraging least auklets from St. Paul I. The presence of Neocalanus spp. in diets at St.
George I. clearly demonstrated that the problem was one of copepod distribution rather than copepod production. In contrast, the lack of $C$. marshallae reflected chronic failures of spring cohorts to persist through summer across a broad region of the shelf in recent years (Coyle et al. 2008).

Transport of shelf water into the vicinity of the Pribilof Is. in summer freshens the upper $50 \mathrm{~m}$ of the water column and enhances the strength of the Middle Front (Stabeno et al. 2008) that lies in the vicinity of the $100 \mathrm{~m}$ isobath and runs just south of the Pribilof Is. (Coachman \& Charnell 1979). Stabeno et al. (2008) proposed one scenario for July to August 2004, in which middle shelf waters expanded southward and westward, dominating the region around the Pribilofs. This kept oceanic water and its zooplankton community away from the Pribilofs (Coyle et al. 2008), sufficiently far that Neocalanus spp. were beyond the foraging range of least auklets from St. Paul I. Auklet diets revealed that such a condition apparently occurred many times in the 2000s, and in 2003 it was so strong that auklets at St. George I. also had limited access to oceanic copepods by late July.

Unusually high atmospheric temperatures over the Bering Sea in the 2000s have had a dramatic effect on warming of the upper layer of the water column over the middle shelf (Stabeno et al. 2007), which has apparently had major consequences to the structure of the zooplankton community there. In 2004, a warm year in a series of warm years, the shelf community was dominated by smaller species of copepods and other taxa of zooplankton compared to 1999, a cooler year in a series of cool years (Coyle et al. 2008). Coyle et al. (2008) have proposed that the hot and deep upper layer effectively capped the water column, and in the absence of extreme storms that might have broken down the strong stratification, essential post-bloom primary production was so depressed that spring cohorts of Calanus marshallae starved later in summer. Post-bloom new (nitrate) primary production over the middle shelf during summer can augment total annual production by as much as 10 to $50 \%$, depending on the frequency and intensity of storms that break down stratification and mix nutrient-laden water sequestered beneath the pycnocline into the euphotic zone (Sambrotto et al. 1986). But, in 2004 for example, the stratification coefficient had a mean value of $90 \mathrm{~J} \mathrm{~m}^{-3}$, or 2 to 3 times greater than that believed to be optimal for summer primary productivity, and thus, zooplankton productivity (Coyle et al. 2008). As a consequence, a floral community of phytoflagellates and other small taxa likely developed and persisted in 2004 and in other recent years with similar conditions, which fostered the shift from larger species of zooplankton to smaller ones. 


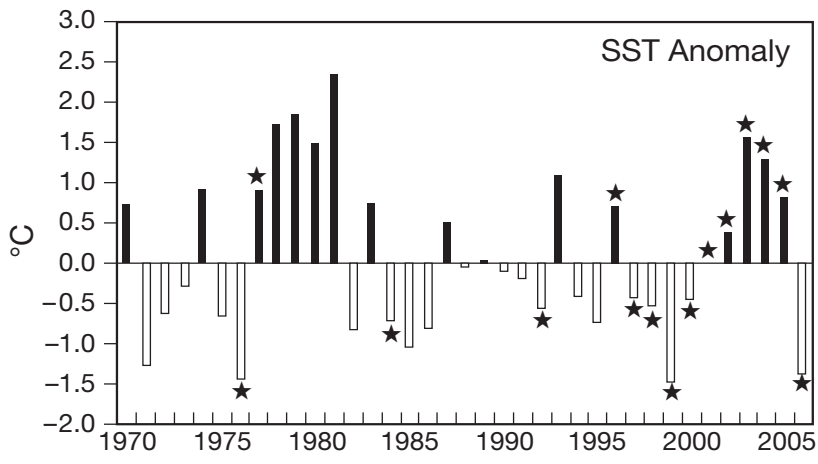

Fig. 4. May sea surface temperature (SST) anomalies in the southeastern Bering Sea (mean temp. $=2.38^{\circ} \mathrm{C}$ ). $\star$ : diet samples obtained at St. Paul I. SST data available at: http:// www.beringclimate.noaa.gov/data/index.php

There is a notable relationship between one index of environmental conditions in the southeastern Bering Sea, May sea surface temperature (SST), and the presence of copepods in auklet diets at St. Paul I. (Fig. 4). In $8 \mathrm{yr}$ of average or cool May SST, Neocalanus spp. and/or Calanus marshallae were available to auklets at St. Paul I. However, warm years for which we have diet data were divided into 2 groups: those prior to 2000 (1977 and 1996), when copepods were available despite positive SST anomalies in May, and those after 2000 (2002 to 2005), when copepods were variably scarce. The difference was not simply a consequence of sampling dates - that is, in 1977 and 1996, copepods were available at times in summer when they were scarce in the 2000s. The difference appears to involve the degree of warming that occurred after May in these 2 eras. For example, in 1996, despite early warming of the surface layer, the temperature of the upper layer above the thermocline did not rise to the levels seen from 2002 to 2005, and the total integrated heat content of the water column was correspondingly lower (Stabeno et al. 2008). Similar data from 1979 to 1981 (Sambrotto et al. 1986) suggest that this situation likely prevailed in 1977 as well. These relationships identify a process-oriented conceptual model that could be used to generate hypotheses for future research.

\section{Consequences of copepod anomalies}

For least auklets, the low abundance of their principal copepod prey also had adverse physiological effects, as revealed by elevated levels of corticosterone, an adrenal hormone indicative of nutritional stress (Benowitz-Fredericks et al. 2008). Corticosterone levels of auklets at St. Paul I. were high in June and July 2003, corresponding to the early decline in copepods that year. In 2004, levels were comparatively low in June and early July, but rose rapidly by late July after copepod abundance collapsed. Field data on aspects of least auklet nesting success or the fitness of chicks at St. Paul I. are not available to evaluate the direct effects of shifts in diets. However, at St. Matthew I. in the central Bering Sea, least auklet chicks grew significantly faster when copepods (Calanus marshallae) were abundant in meals brought by adults (Springer et al. 1986); there are strong relationships between least auklet demographic parameters and the amount of copepods in chick diets in the Aleutian Islands (Jones \& Williams 2007); and at St. Lawrence I. in the northern Bering Sea, the daily survival rate of least auklet chicks was proportional to the amount of copepods in their diets (Gall et al. 2006). Work on other species of seabirds has found strong negative correlations between stress and various demographic parameters (Kitaysky et al. 2007). Thus, it is reasonable to suspect that the feeding environment for least auklets at St. Paul I. from 2002 to 2005 was detrimental to the health of the population.

In an important respect, the very low abundance of Calanus marshallae around the Pribilof Is. in recent years has been just one symptom of the much larger, expansive change in the structure of the pelagic community of the continental shelf of the eastern Bering Sea. Coyle et al. (2008) reported a shift in the size spectrum of zooplankton over the shelf from larger (e.g. C. marshallae) to smaller taxa, and suggested that if the condition persisted it would be expected to have numerous repercussions in the pelagic food web for various consumer species of commercial, aesthetic, and ecological importance. Effects of such a shift would be exacerbated around the Pribilof Is., and elsewhere along the outer shelf, by the early expansion of middle shelf waters seaward in summer and the associated offshore displacement of the community of larger oceanic plankton, including notably Neocalanus spp.

\section{CONCLUSIONS}

Least auklets at St. Paul I., and probably other planktivores in the region of the Pribilof Is., were subjected to prey (copepod) shortage from 2002 to 2005, apparently brought on by unusually high water temperatures over the continental shelf. A single oceanographic research cruise in summer 2004 documented characteristics of the physical environment and plankton communities that were anomalous compared to previous observations in cooler years. By studying diets of least auklets at the Pribilofs, we extended the temporal and spatial scales of our knowledge of these conditions, and this gave us a much improved under- 
standing of responses of the ocean ecosystem to climate warming. There is no evidence that such conditions occurred between the mid-1970s and 2002.

Least auklets sample their environment very efficiently and effectively-despite a limitation on the depth to which they can dive (about $15 \mathrm{~m}$ ), they are able to forage over considerable distances (up to at least $80 \mathrm{~km}$ from their colonies) - and they provide a valuable index of abundance of ecologically important species of zooplankton. The information contained in their diets is large and the cost of acquiring it is small. They should therefore be included and emphasized in any plan to monitor environmental variability in the Bering Sea.

The stories that scientists have to tell about expectations for future impacts of global warming on ecosystems are enriched with integrated observations that link changes in oceanographic conditions with predator and prey data. Collections and analyses of diet data from least auklets in the Bering Sea provide a wealth of information from which we can better understand the ecosystem-scale consequences of climate change. This story tells us that if warming trends continue (e.g. Overland \& Wang 2007), there may be serious repercussions to auklets and other planktivorous species in the eastern Bering Sea. Communities and ecosystems are not static, but change over time, yet changes such as those reported here and by others, apparently in response to unusual warming of the Bering Sea in this century, appear to be altering in fundamental ways the structural and functional elements of the ecosystem. We do not know how or if these changes might alter food webs crucial to this highly productive sea over the long term, but they should be a cause for concern to people who depend upon its vast resources and to those charged with their management.

Acknowledgements. We thank numerous field assistants of the US Fish and Wildlife Service and University of Alaska Fairbanks for collecting auklet diet samples, K. Turco for enumerating prey in the samples, and G. Van Vliet and 3 anonymous reviewers for helpful comments. Funding for this study was provided by the US Fish and Wildlife Service and by the North Pacific Research Board to the project Regime Forcing and Ecosystem Response (REFER). Additional logistical support was provided by the National Marine Fisheries Service and the Stewardship Program at St. Paul I. This is NPRB Publication Number 92.

\section{LITERATURE CITED}

Anderson PJ, Piatt JF (1999) Community reorganization in the Gulf of Alaska following ocean climate regime shift. Mar Ecol Prog Ser 189:117-123

Bedard J (1969) Feeding of the least, crested and parakeet auklets on St. Lawrence Island, Alaska. Can J Zool 47: 1025-1050
Benowitz-Fredericks ZM, Shultz MT, Kitaysky AS (2008) Stress hormones suggest opposite trends of food availability for planktivorous and piscivorous seabirds in two years. Deep-Sea Res II (in press)

Bradstreet MSW (1985) Chapter IV. Feeding studies. In: Johnson SR (ed) Population estimation, productivity, and food habits of nesting seabirds at Cape Peirce and the Pribilof Islands, Bering Sea, Alaska. Report by LGL Ecological Research Associates, Inc., to Minerals Management Service, Anchorage, AK, p 257-306

Coachman LK (1986) Circulation, water masses, and fluxes on the southeastern Bering Sea shelf. Cont Shelf Res 5: 23-108

Coachman LK, Charnell RL (1979) On lateral water mass interaction-a case study, Bristol Bay, Alaska. J Phys Oceanogr 9:278-297

Cooney RT (1981) Bering Sea zooplankton and micronekton communities with emphasis on annual production. In: Hood DW, Calder JA (eds) The eastern Bering Sea shelf: oceanography and resources, Vol 2. NOAA, Juneau, AK, p 947-974

Coyle KO, Pinchuk AL, Eisner LB, Napp JM (2008) Zooplankton species composition, abundance and biomass on the eastern Bering Sea shelf during summer: the potential role of water column stability and nutrients in structuring the zooplankton community. Deep-Sea Res II (in press)

Dalsgaard J, St John M, Kattner G, Müller-Navarra D, Hagen W (2003) Fatty acid trophic markers in the pelagic marine environment. Adv Mar Biol 46:225-340

Dragoo DD, Byrd GV, Irons DB (2006) Breeding status, population trends, and diets of seabirds in Alaska, 2003. US Fish and Wildlife Service Report AMNWR 04/15, Homer, AK

Ebbesmeyer CC, Cayan DR, McLain FH, Peterson DH, Redmond KT (1991) 1976 step in the Pacific climate: forty environmental changes between 1968-1975 and 1977-1985. In: Betancourt JL, Tharp VL (eds) Proc 7th Ann Pacific Climate Workshop Interagency Ecol Stud Prog, Tech Rep 26. California Dept. of Water Resources, Sacramento, CA, p 129-141

Flint MV, Golovkin AN (2002) How do planktivorous least auklets (Aethia pusilla) use foraging habitats around breeding colonies? Adaptation to mesoscale distribution of zooplankton. Oceanology (Suppl) 42(1):114-121

Francis RC, Hare SR (1994) Decadal-scale regime shifts in the large marine ecosystems of the north-east Pacific: a case for historical science. Fish Oceanogr 3(4):279-291

Gall AE, Roby DD, Irons DB, Rose IC (2006) Differential response in chick survival to diet in least and crested auklets. Mar Ecol Prog Ser 308:279-291

Grebmeier JM, Overland JE, Moore SE, Farley EV and others (2006) A major ecosystem shift in the northern Bering Sea. Science 311:1461-1464

Hare SR, Mantua NJ (2000) Empirical evidence for North Pacific regime shifts in 1977 and 1989. Prog Oceanogr 47:103-146

Hunt GL Jr, Harrison NM (1990) Foraging habitat and prey taken by least auklets at King Island, Alaska. Mar Ecol Prog Ser 65:141-150

Hunt GL Jr, Mayer B, Rodstrom W, Squibb R (1978) Reproductive ecology, foods and foraging areas of seabirds nesting on the Pribilof Islands. Environ Assess Alask Cont Shelf 1:570-775

Hunt GL Jr, Burgesson B, Sanger GA (1981) Feeding ecology of seabirds of the eastern Bering Sea. In: Hood DW, Calder JA (eds) The eastern Bering Sea shelf: oceanography and resources, Vol 2. NOAA, Juneau, AK, p 629-648 
IPCC (Intergovernmental Panel on Climate Change) (2007) Climate change 2007: the physical science basis. IPCC Secretariat, Geneva

Iverson RL, Coachman LK, Cooney RT, English TS and others (1979) Ecological significance of fronts in the southeastern Bering Sea. In: Livingston RJ (ed) Ecological processes in coastal and marine systems. Plenum Press, New York, p 437-466

Iverson SJ, Springer AM, Kitaysky AS (2007) Seabirds as indicators of food web structure and ecosystem variability: qualitative and quantitative diet analyses using fatty acids. Mar Ecol Prog Ser 352:235-244

Jones IL (1993) Least auklet (Aethia pusilla). In: Poole A, Gill F (eds) The birds of North America, No. 69. The Academy of Natural Sciences, Philadelphia, PA, and The American Ornithologists' Union, Washington, DC

Jones IL, Williams JC (2007) On the meaning of annual variation in auklet (Aethia spp.) demographic parameters and chick diet. Abstract of presentation at the Alaska Marine Science Symposium, Jaunary 2007, Anchorage, AK. Available at www.alaskamarinescience.org

Kitaysky AS, Piatt JF, Wingfield JC (2007) Stress hormones link food availability and population processes in seabirds. Mar Ecol Prog Ser 352:245-258

Obst BS, Russell RW, Hunt GL Jr, Eppley ZA, Harrison NM (1995) Foraging radii and energetics of least auklets (Aethia pusilla) breeding on three Bering Sea islands. Physiol Zool 68:647-672

Overland JE, Wang M (2007) Future climate of the North Pacific Ocean. EOS Trans Am Geophys Union 88:178-182

Editorial responsibility: Howard Browman (Associate Editorin-Chief), Storebø, Norway
Roby DD, Brink KL (1986) Breeding biology of Least Auklets on the Pribilof Islands, Alaska. Condor 88:336-346

Sambrotto RN, Niebauer HJ, Goering JJ, Iverson RL (1986) Relationships among vertical mixing, nitrate uptake, and phytoplankton growth during the spring bloom in the southeast Bering Sea middle shelf. Cont Shelf Res 5: 161-198

Smith SL, Vidal J (1984) Spatial and temporal effects of salinity, temperature and chlorophyll on the communities of zooplankton in the southeastern Bering Sea. J Mar Res 42:221-257

Smith SL, Vidal J (1986) Variations in the distribution, abundance, and development of copepods in the southeastern Bering Sea in 1980 and 1981. Cont Shelf Res 5:215-240

Springer AM, Roseneau DG (1985) Copepod-based food webs: auklets and oceanography in the Bering Sea. Mar Ecol Prog Ser 21:229-237

Springer AM, Roseneau DG, Lloyd DS, McRoy CP, Murphy EC (1986) Seabird responses to fluctuating prey abundance in the eastern Bering Sea. Mar Ecol Prog Ser 32: $1-12$

Springer AM, McRoy CP, Flint MV (1996) The Bering Sea Green Belt: shelf edge processes and ecosystem production. Fish Oceanogr 5:205-223

Stabeno PJ, Bond NA, Salo SA (2007) On the recent warming of the eastern Bering Sea shelf. Deep Sea Res II 54: 2599-2618

Stabeno PJ, Mordy C, Righi D, Salo SA (2008) An examination of the physical forcing around the Pribilof Islands, 2004. Deep-Sea Res II (in press)

Submitted: March 22, 2007; Accepted: September 3, 2007 Proofs received from author(s): December 14, 2007 